\title{
Coastal Dynamics and Implication for Development of the Fishing Communities Along the Shoreline Region of Toube, Cameroon
}

\author{
Oben Alexander Tataw ${ }^{1}$, Wanie Clarkson $\mathrm{Mvo}^{2,}$, , Ndi Roland Akoh ${ }^{3}$, Kang Edwin Mua ${ }^{2}$ \\ ${ }^{1}$ Department of Geography, University of Buea, Buea, Cameroon \\ ${ }^{2}$ Department of Geography and Planning, The University of Bamenda, Bambibli, Cameroon \\ ${ }^{3}$ Department of Geography, University of Yaounde I, Yaounde, Cameroon \\ Email address: \\ obenalex@gmail.com (O. A. Tataw),wanimvo@yahoo.co.uk (W. C. Mvo), ndirolisonakoh@yahoo.com (N. R. Akoh), \\ kangemua@gmail.com (K. E. Mua) \\ ${ }^{*}$ Corresponding author
}

\section{To cite this article:}

Oben Alexander Tataw, Wanie Clarkson Mvo, Ndi Roland Akoh, Kang Edwin Mua. Coastal Dynamics and Implication for Development of the Fishing Communities Along the Shoreline Region of Toube, Cameroon. Landscape Architecture and Regional Planning. Vol. 6, No. 2, 2021, pp. 37-45. doi: 10.11648/j.larp.20210602.13

Received: May 21, 2021; Accepted: June 18, 2021; Published: June 29, 2021

\begin{abstract}
The world's coastlines provide essential development benefits to most communities for livelihood sustenance. The proximity of communities to coastlines elects the need to exploit the water resources through fishing and transportation. Given that coastlines are subjected to changes, this study intends to investigate coastal dynamics and implication for development of the fishing communities along the shoreline region of Toube. A descriptive research design was adopted with a sample size of 300 respondents which employed a random sampling technique. Data was collected from both primary and secondary sources and was analyzed qualitatively and quantitatively by the use of arithmetic mean and ArcGIS 10.2. The coastal dynamics between 1984 and 2017 were observed using shoreline GPS Way Point that was matched by Landsat images of 1984, 2000 and 2017. Findings showed that prolonged backwash process caused by sea level rise provoked coastal erosion and submergence of shoreline communities. The results revealed that between 1984 and 2017, the shoreline of Toube has been retreating at a rate of $9.56 \mathrm{~m}$ per year. The retreat rate equally varies along Toube coastlines revealing that Cap shoreline has retreated some $452.4 \mathrm{~m}$ between 1984 and 2017 while Itiekot-Chekiri and Small Toube retreated by $254.87 \mathrm{~m}$ and $239.61 \mathrm{~m}$ respectively between 1984 and 2017. These coastal fishing communities are vulnerable to coastal erosion, settlement submergence, destruction of fishing barns, displacement of people and disruption of coastal activities with huge socio-economic losses. The study opts for the stabilization of the shorelines through the use of sand bags, sea walls and the creation of buffer zone with mangrove trees in order to reduce the exposure of the fishing communities to the intensity of the coastal dynamics in Toube.
\end{abstract}

Keywords: Coastline, Dynamics, Implications, Development, Fishing Communities, Toube

\section{Introduction}

Coastal inhabitants in the world are already suffering from consequences of extreme climate events as indicated in retreating shorelines, threatening sand dunes and coastal lagoons $[1,2]$. Shoreline change is considered one of the most dynamic processes in coastal areas [3,4]. Coastal areas are often perceived as perfect vacation spots by most of the population who can afford a vacation. But most beaches have stories beyond vacations and tourists; they have many other aspects like the population of fishermen who live and make a living out of the natural resource and the changing shorelines [5]. With an increase in the degree of climate change, shorelines around the globe especially sandy coastlines are experiencing high coastal retreat or shoreline erosion with the rates expected to increase due to sea level rise [6-8]. Coastal erosion which was not a serious threat in the past is now a major threat and thus a pre-occupying issue to researchers due largely to climate change. This is because coastal islands 
and other coastal features are gradually disappearing. Worldwide rise in sea level would inundate wetlands and low lands; erode shorelines; exacerbate coastal flooding; increase the salinity of estuaries and aquifers (and otherwise impair water quality); alter tidal ranges in rivers and bays; change the locations where rivers deposit sediments; change the heights, frequencies and other characteristics of waves; and decrease the amount of light reaching the sea floor. Over the past decades, there is increasing evidence of sea level rise-up to 2 to $3 \mathrm{~mm} / \mathrm{yr}$ [6-8], which suggests an increase in the vulnerability of low-lying coasts (such as Toube in Cameroon) already subjected to increasing storm surges and floods. This disrupts basic coastal livelihood activities such as fishing. This study diagnoses the implications of coastal dynamics on the fishing communities along the shoreline of Toube and suggest short and long term sustainable livelihood coping strategies.

\section{Literature Review}

Coastal erosion is a global issue as all the continental margins or coastal regions of the Americas, Europe, Africa, Asia, and Australia are all affected by it. In Africa, coastal erosion is a severe problem affecting the coastal regions of the continent. According to [9] and [10], the entire West African Coastline running from the Orange dunes in Mauritania to the dense tropical forests in Cameroon is predicted to be submerged by the end of the $21^{\text {st }}$ century as a direct consequence of climate change. This implies that, the rich biodiversity and other benefits derived from this area will be short-lived. In Cameroon, the effects of climate change as a contributor to sea level rise is greatly felt as coastal areas are experiencing severe coastal erosion. According to [5], coastal flooding from saline water incursion results in ecological stress through wetland loss, inundation and erosion, while the lagoon-creek complex is affected by hydro-geomorphic changes with adverse environmental consequences on the coastal settlements (settlement submergence, house damage and landscape deformation).
Fishing is a lucrative economic activity that sustains the livelihoods of millions of coastal inhabitants who are directly or indirectly involved in it. The benefits that coastal fishing communities enjoy as a result of their coastal location is, however, a function of the changes in the shoreline which is determined by dynamic coastal processes such as erosion, accretion and submergence of the land. Fishing is a major source of revenue for most West African economies especially in island nations like Cape Verde and other drought-stricken nations like Senegal. According to [11], the fishery sector in Cape Verde contributes over $40 \%$ of export earnings and 5\% of GDP; in Mauritania fishing accounts for $25 \%$ of state revenue and over $50 \%$ of export earnings; in Senegal over 600,000 people earn income to sustain their livelihood with fishing being the primary export sector of over $30 \%$ of total export earnings in the nation. Looking at the number of people that engage in fishing in Africa and across the globe and the financial returns from the activity, it is glaring that fishing is a livelihood sustaining activity for millions of people especially those in developing nations and the globe at large.

Toube like other coastal environment is experiencing the effects of coastal erosion putting the main source of their livelihood (fishing) at stake as their barns and houses are destroyed as a result of shoreline submergence. A study by [12] confirmed that settlements are differentially vulnerable in the Cameroon's mangrove coastal areas as they get submerged, damaged and the landscape deformed due to coastal flooding as a result of sea level rise. Although coastal erosion has been recognized by scholars and government institutions in Cameroon, the intricacy of the problems faced by the local adjacent communities (loss of land, property, capital assets and livelihoods) have not gained significant traction in related literature [5]. Due to the importance of the fishing in this community of Cameroon, it expedient and mandatory to identify, diagnose and lay to bare the extent to which the processes and the degree of coastal dynamics have convulsed the activities of fishing in the locality of Toube in the Littoral region of Cameroon.

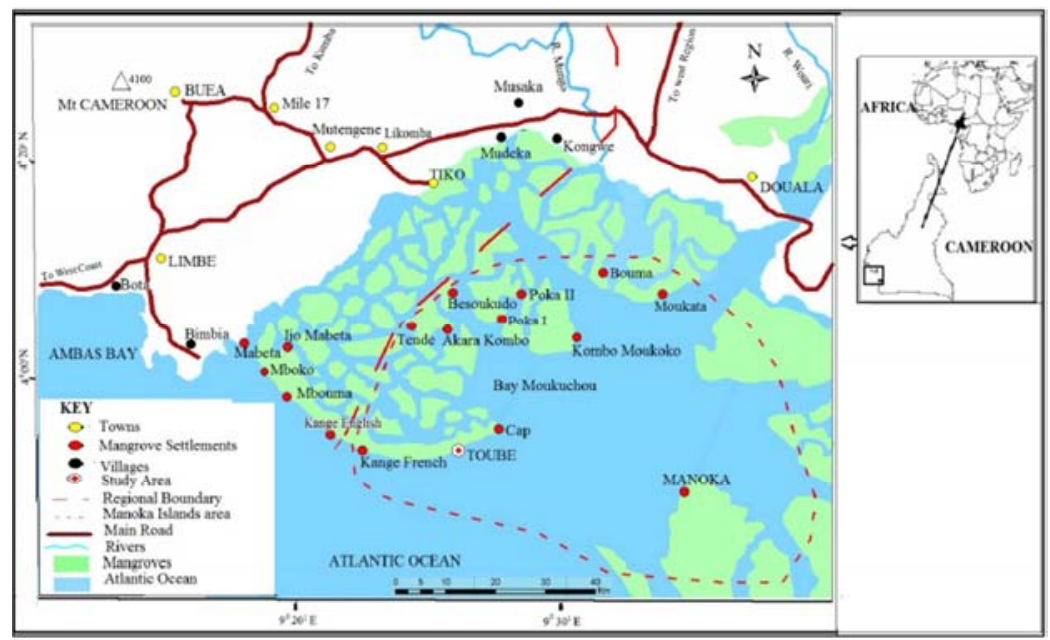

Source: Culled from Google Earth, (2017) and Munji et al., (2013).

Figure 1. Location of Toube in Manoka Sub Division. 


\section{Materials and Method}

\subsection{Location}

Toube is a fishing island community found in the coastal mangroves of the Wouri Estuary, Littoral Region of Cameroon. It is one of the many island settlements (Kombo Moukoko, moukkata, Akarakombo, Poka, Tende, Kange French and Besoukudo) that make up the Manoka Sub Division of the Wouri Division in the Littoral Region of Cameroon. It is located between longitudes $09^{\circ} 24 \mathrm{E}$ to $9^{\circ} 28 \mathrm{E}$ and latitudes $03^{\circ} 52 \mathrm{~N}$ to $3^{\circ} 54 \mathrm{~N}$ (Figure 1). Some of the islands being the Ntoube, Kange French, Toube, Cap and Manoka are barrier islands exposed to the incoming waves from the Atlantic Ocean, making them vulnerable to the effects of sea level rise and fall with coastal submergence and erosional processes.

The Itiekot, Big Toube, New Town, Chekiri, Small Toube and Cap are some of the built-up areas along the Toube coastline. These are water dependent communities whose activities are linked to the exploitation of the shorelines for fishing and transportation.

\subsection{Methods}

The descriptive research method was employed alongside a combination of the survey and observational research designs were used to generate data from both primary and secondary sources. Secondary sources of data were obtained from libraries where textbooks and journals were consulted. Institutional sources were also employed such as the published reports from the Intergovernmental Panel on Climate Change (IPCC), National Oceanic and Atmospheric Administration (NOAA) and the National Oceanography Center (NOC). Primary data sources included a well-structured questionnaire, field measurements and observations. The coastlines of Itiekot to Chekiri, Cap and Small Toube were visited to observe the daily movement of the sea waves together with fishing activities along the area. The target population for this study consisted of people who are permanently resident in Toube and who depend on fishing directly or indirectly (fishermen, fish processors, fish marketers and buyers, wood exploiters, local administrative authorities, farmers and petty traders). The target population was stratified into three stratas (Crayfish, fishers and processors, Fish Fishers and processors and those involved in other activities). The sample size for the distribution of questionnaires consisted of 320 respondents randomly selected from these three strata for a period of three months when fishing activities are booming (July, August and September 2017). Such a sample size (320) represents $10 \%$ of the total population of 3189 inhabitants in the fishing community of Toube (Table 1). The stratified random sampling technique was used in sampling the target population.

Table 1. Distribution of questionnaires to the different fish dealers in Toube.

\begin{tabular}{lll}
\hline Strata & Number of Questionnaires & Percentage of respondents \\
\hline Crayfish, fishers and processors & 160 & 50 \\
Fish Fishers and Processors & 112 & 35 \\
Other activities & 48 & 15 \\
Total & 320 & 100 \\
\hline
\end{tabular}

Source: Field Work (2017).

Based on a sample size of 320 from the three strata, $50 \%$ of the questionnaires were administered to stratum 1 (crayfish fishers and processors), 35\% to stratum 2 (fish fishers and processors) while $15 \%$ for stratum 3 (other activities). Such a disparity in the distribution of questionnaires according to strata is because during preliminary studies, it was observed that there were more crayfish boats and processing units than those for fish. This is because industrial trawlers have completely specialized in the catching of fish. Local inhabitants thus switched from catching big fish catching to crayfish.

In order to determine the spatio-temporal dynamics of shoreline change in a bid to examine its implications on fishing in Toube, the Google Earth Images of 1984, 2000 and 2016 alongside 2017 shoreline and the GPS coordinates (waypoints) were used in a time series analysis. The Google Earth historical tool was used to back date the image to 1984 where the 1984 shoreline was traced and the images for 2000 (latest image for Big and Small Toube) and 2016 (latest image for Cap) were also traced with different colours for easy identification. After tracing the different shorelines, the recent 2017 coordinates (waypoint) was uploaded after which the distances between the traced shorelines were established. This method established the shoreline changes (in average rate per year and average rate from 1984 to 2017) which were used to determine whether the shoreline is retreating or advancing. The 1984, 2000 and 2016, with 2017 shoreline GPS were then imported into ArcGIS 10.2 to determine the evolution of Toube from 1984 to 2017. The spatio-temporal dynamics of the shoreline was presented using figures for better understanding.

\section{Findings and Discussions}

The processes responsible for the change in the shoreline of Toube are erosion and subsidence of land due mainly to sea level rise. These two processes have worked together in altering the nature of the shoreline of Ntoube in two principal phases.

\subsection{Spatio-Temporal Dynamics of the Toube Coastline Between 1984 and 2017}

Findings in line with the spatio-temporal dynamics of the Toube shoreline took into consideration the erosional processes of shoreline sediments, coastal submergence and 
the rate of shoreline retreats over time.

\subsubsection{Coastal Erosion in the Toube Shoreline}

Given the low altitude of Toube $(<4 \mathrm{~m}$ above sea level) and the massive presence of unconsolidated sandy soils, the zone is extremely vulnerable to the caprices of sea level rise, tides and storm surges. Field investigation revealed that during periods of high tides with maximum tidal heights of approximately $3 \mathrm{~m}$ and accompanied by storms surges, the shoreline of Toube is seriously affected by erosion. The land is easily inundated by strong swash which washes sandy and other materials from the shoreline to the marshy creek areas. As a result, the shoreline is forced to shift backwards as the waves erodes and deposits the material in the marshy creeks. As erosion takes place in the shoreline, a new dry land is created inland due to the increase deposition of materials in the marshy creeks as manifested through shoreline drifting.

\subsubsection{Coastal Subsidence in the Toube Shoreline}

Findings also revealed that the Toube coastline has been experiencing remarkable subsidence of materials over time. As the shoreline is being eroded, a backward shift of shoreline materials take place whereby these materials are transported and deposited in the creeks leading to the formation of new dry land. These dry areas are temporarily colonized for settlement construction. As such the altitude of the eroded shoreline areas falls to $<1 \mathrm{~m}$ above sea level making the entire area to be submerged by the Atlantic Ocean. As erosion continues, the eroded areas keep submerging. The sea thus advances while the land shrinks in size due to continuous erosion and subsidence. Over time, successive build up areas and vegetated areas are submerged forcing people to retreat backwards as the sea keeps advancing and submerging the shoreline area (Figure 2). However, the shoreline materials are transferred inland where they are deposited in the marshy creek area. Due to erosion and subsidence, areas which were once land are now inside the water implying that several generations of buildup areas are now under the Atlantic Ocean.

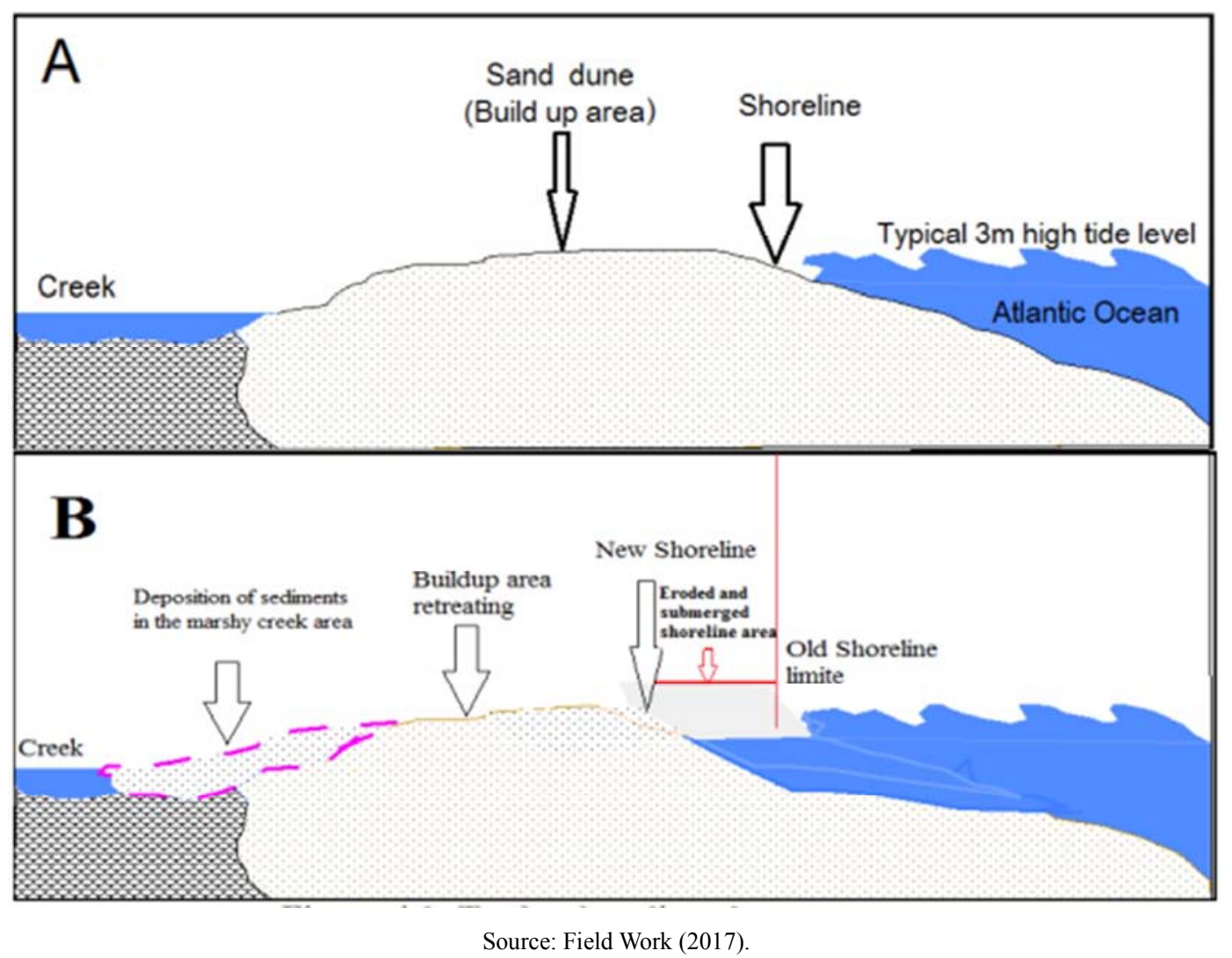

Figure 2. Response of the Toube Shoreline to Tidal Effect.

Based on the fact that Toube is found in the Wouri Estuary that is a depositional environment, the retreating shoreline change of Toube is indispensable. On the other hand, with the increase in sea level and the low-lying nature of the area, the erosion and subsidence of low-lying sandy coastlines like Toube cannot be denied. This is because natural factors such as (sea level rise, tides, low elevation and unconsolidated soil type as well as anthropogenic causes like deforestation have made it possible for this depositional coastline to experience accelerated erosion and subsidence that has resulted in the retreat of its shoreline.

\subsection{Coastal Dynamic Trends and Implications Along the Toube Shoreline}

Three coastlines were observed, monitored and analysis in line with the coastline dynamics of Toube. The dynamic trend of the coastline of Cap, Etiekot-Chekiri and Small Toube were determined from landsat images between 1984 and 2017. 


\subsubsection{Shoreline Change (Retreat) in the Cap Coastline}

Due to erosion and subsidence, areas which were once land are now inside water implying that several generations of build-up areas are now submerged under the Atlantic Ocean. Such rates of shoreline changes have been exemplified and derived from four different points on the 1984 and 2016 shoreline with respect to the various settlement areas that make up Toube in Figures 3 (Cap retreat), 4 (Itiekot to Chekiri retreat) and 5 (Small Toube retreat).

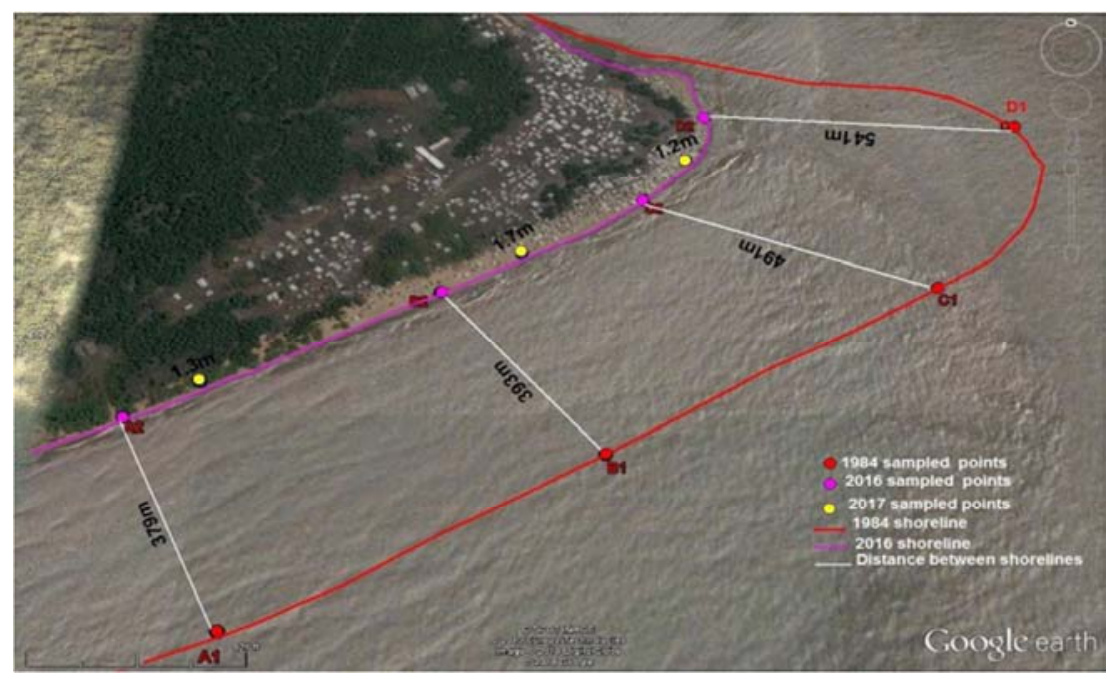

Figure 3. Rate of Shoreline Change (retreat) for Cap (1984-2017).

Figure 3 shows that different rates of retreats were noted at different sampled points (A1-379 m, B1-393 m, C1 $491 \mathrm{~m}$ and D1 $541 \mathrm{~m}$ ) giving an average shoreline retreat rate of 451 $\mathrm{m}$ and an annual retreat of $14.09 \mathrm{~m}$. Between 2016 and 2017, the distance of the 2016 shoreline and the 2017 coordinate presents an average of $1.4 \mathrm{~m}$. This revealed an average rate of shoreline change for Cap to stand at $452.4 \mathrm{~m}$ from 1984 to 2017 and an annual average of $13.70 \mathrm{~m}$. This shows that Cap has experienced a greater rate of shoreline retreat than any other shoreline region of village. The annual retreat for the entire area stands at $9.56 \mathrm{~m}$ per year while that for Cap stands at $13.70 \mathrm{~m}$ with a difference of $4.14 \mathrm{~m}$.

\subsubsection{Rates of Shoreline Change (Retreat) for Itiekot to Chekiri}

The coastline of Itiekot to Chekriri has between 1984 and 2017 witnessed significant retreat as a result of the rise and fall in sea level which in turn trigger coastal erosion of materials over time (Figure 4). Different rates of retreats were noted (A1 to $A 2=261 \mathrm{~m}, \mathrm{~B} 1$ to $\mathrm{B} 2=230 \mathrm{~m}, \mathrm{C} 1$ to $\mathrm{C} 2=218 \mathrm{~m}$ and $\mathrm{D} 1$ to $\mathrm{D} 2=234 \mathrm{~m}$ ) giving an average shoreline retreat rate of $235.75 \mathrm{~m}$ and the retreat from 2000 to 2017 (18 $\mathrm{m}, 24.1 \mathrm{~m}, 19 \mathrm{~m}, 15.4 \mathrm{~m})$ with a retreat rate of $19.12 \mathrm{~m}$. The results showed that between 1984 and 2017, an average retreat of the shoreline along the Itiekot-Chekiri axis was $254.87 \mathrm{~m}$ and an annual average of $7.72 \mathrm{~m}$.

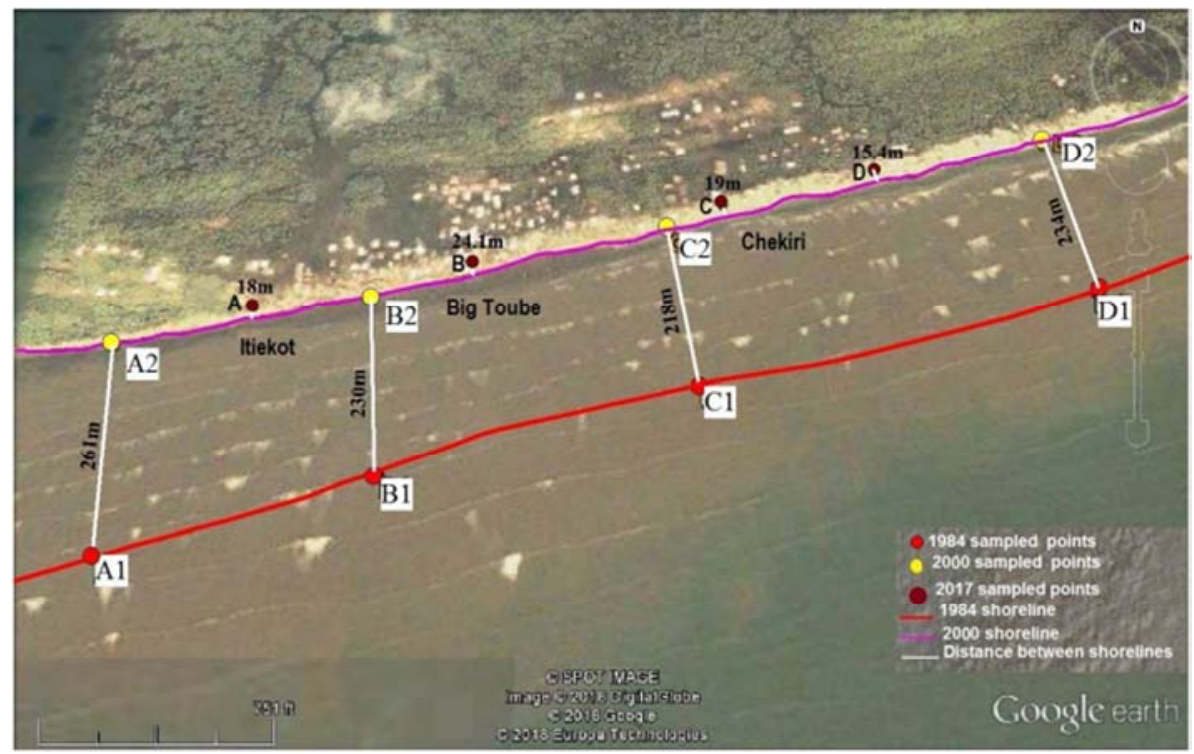

Figure 4. Rates of Shoreline Change (retreat) along Itiekot-Chekiri Axis. 
The average annual retreat was therefore lower than the general annual retreat of $9.56 \mathrm{~m}$ indicating a difference of $1.84 \mathrm{~m}$. Based on the annual and general retreat values from Itiekot to Chekiri, the areasbare ranked second in terms of the shoreline retreat in Toube.

\subsubsection{Rate of Shoreline Change (Retreat) for Small Toube}

The analysis of coastal drifting was carried out for Small Toube between 1984 and 2017 (Figure 5), the shoreline changes from 1984 to 2000 was derived from four different points on the 1984 shoreline and the 2000 shoreline with different rates of retreats $(200 \mathrm{~m}, 181 \mathrm{~m}, 224 \mathrm{~m}$ and $250 \mathrm{~m})$ giving an average shoreline retreat rate of $213.75 \mathrm{~m}$ and retreat from 2000 to $2017(26.6 \mathrm{~m}, 19 \mathrm{~m}, 34.1 \mathrm{~m}, 26.6 \mathrm{~m}$, $18.8 \mathrm{~m}$ and $29.9 \mathrm{~m}$ ) with a retreat rate of $25.86 \mathrm{~m}$ which is above the $19.12 \mathrm{~m}$ for Itiekot to Chekiri. The shoreline of Small Toube revealed that $239.61 \mathrm{~m}$ of the land has been retreated between 1984 and 2017 with an annual average of $7.26 \mathrm{~m}$ which is also lower than the general annual retreat of $9.56 \mathrm{~m}$. The gap or difference shows $1.31 \mathrm{~m}$ which is equally lower than what is observed along the Itiekot-Chekiri axis with annual retreat difference of $1.84 \mathrm{~m}$. The results on the rates of shoreline change goes a long way to confirm the hypothesis on of this study which states that "Toube fishing port has retreated significantly relative to its position in 1984" as Toube has experienced an average shoreline retreat of $315.67 \mathrm{~m}$ from 1984 to 2017 at an annual rate of $9.56 \mathrm{~m}$. This shows that, the role of sea level rise cannot be under estimated as this depositional coastline is now retreating due to accelerated erosion and submergence. This confirms the view of [13], who noted that as sea level rises in response to global climate changes, small islands will lose a significant portion of their land through ensuing erosion processes.

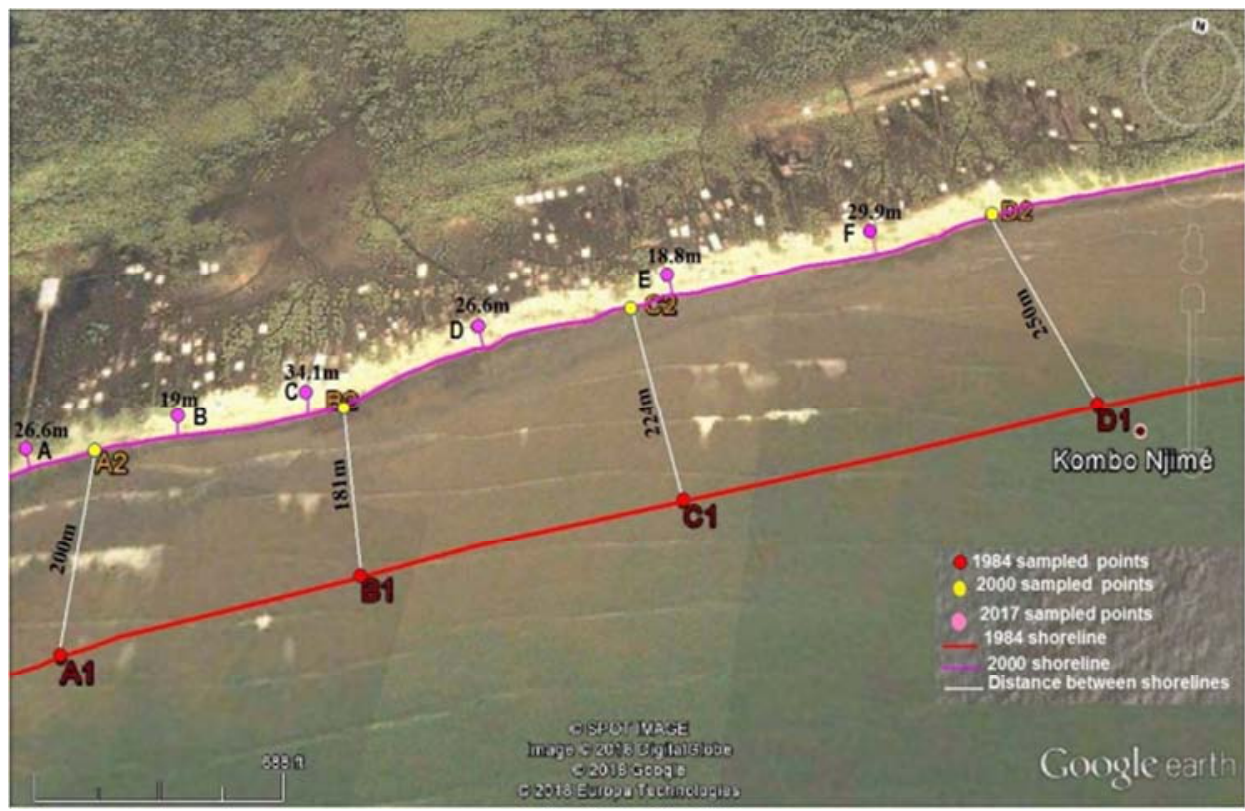

Figure 5. Rate of Shoreline Change (Retreat) for Small Toube.

Table 2. presents the general retreat of the Toube coastline between 1984 and 2017. The results revealed that the shoreline has been highly vulnerable to the incidence of erosion which equally exposes the shoreline to coastal subsidence in Toube over time.

\begin{tabular}{lllll}
\hline \multirow{2}{*}{ Localities } & \multicolumn{4}{l}{ Measurement sites between 1984 and 2017 (m) } \\
\cline { 2 - 5 } & A1-A2 & B1-B2 & C1-C2 & D1-D2 \\
\hline Cap & 379 & 393 & 491 & 541 \\
Etiekot-Chekiri & 261 & 230 & 218 & 234 \\
Small Toube & 200 & 181 & 224 & 252 \\
\hline
\end{tabular}

Source: Landsat Images Analysis of 1984 and 2017.

By implication, the Cap shoreline has been the most vulnerable and exposed to erosion from sea retreat action. The area revealed a total of $452 \mathrm{~m}$ of land surface already retreated as a result of sea dynamic indicence. Etiekot and Chekiri shoreline together with the Small Toube shoreline revealed increasing threat and disappearance of the shoreline over time. The results revealed that $235.75 \mathrm{~m}$ and $213.75 \mathrm{~m}$ of the shoreline retreated respectively in these areas. The land retreat process is a threat to the fishing communities who are equally faced with the rising and falling effects of sea tides.

\subsection{Indicators of Shoreline Retreat (Erosion and Submergence)}

The presence of the Cap antenna and eroded/submergence of the coastal settlements are some of the indicators of shoreline retreat (Figure 6). First, the submerging antenna found in Cap stands as the most glaring evidence of shoreline change due to erosion and submergence. 


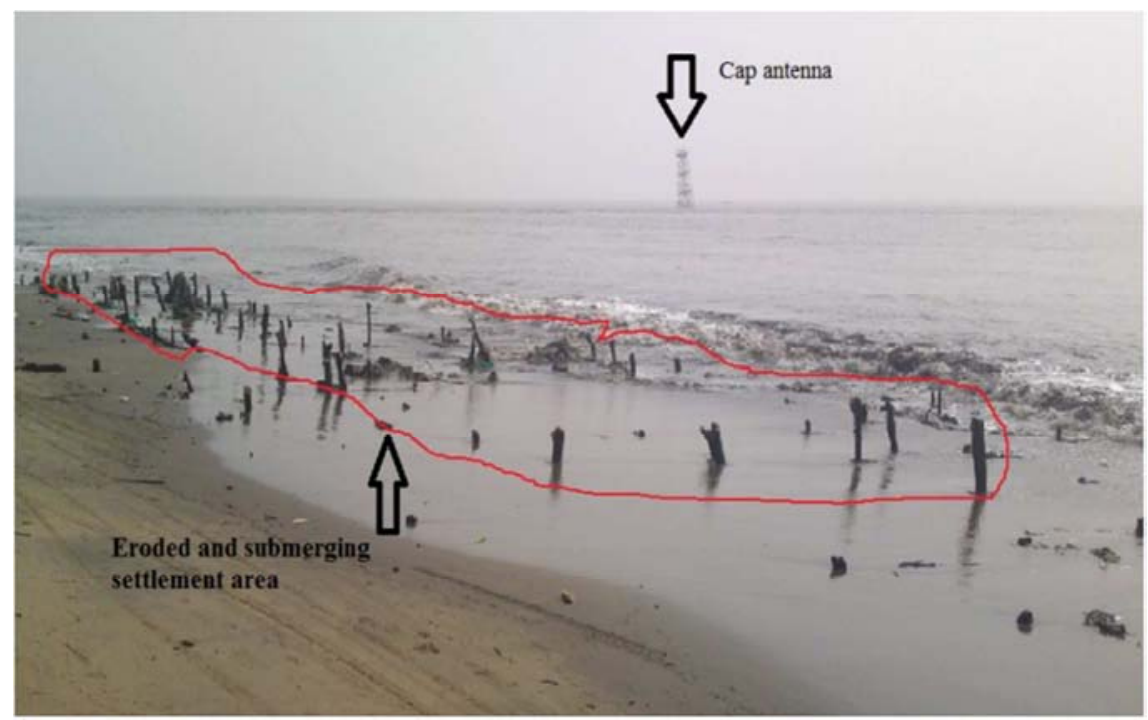

Source: Field Work (2017).

Figure 6. Cap Antenna indicator of coastal retreat between 1984 and 2017.
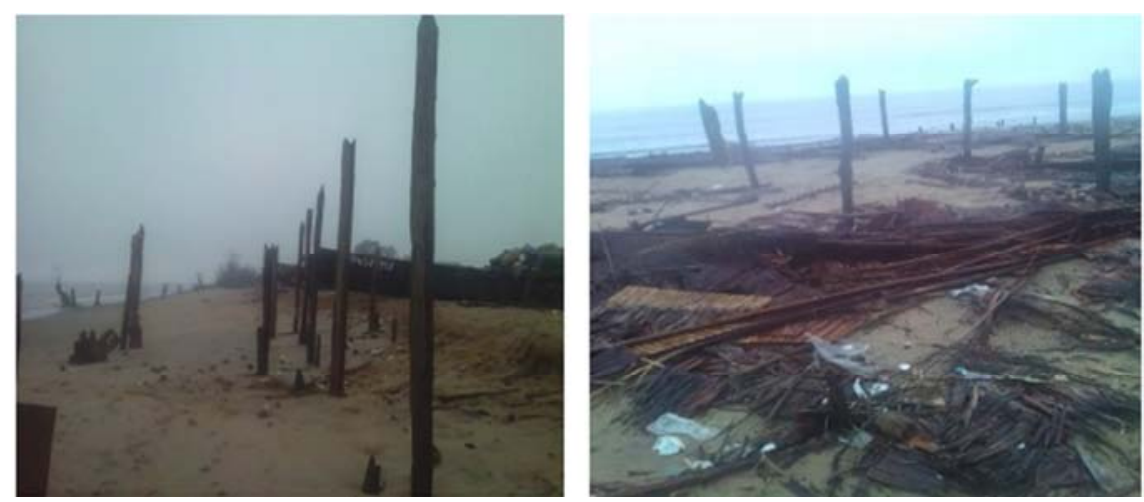

Source: Field Work (2017).

Figure 7. Destroyed houses and barns along the shoreline of Cap in Toube.

The Cap antenna was constructed and planted about $100 \mathrm{~m}$ within the mangrove vegetation at the outskirts of Cap. The distance between this antenna (when it was on land) to the shoreline was estimated to be about $160 \mathrm{~m}$. Current evidence, however, shows that the antenna is some $114 \mathrm{~m}$ inside the Atlantic Ocean. Secondly, the presence of numerous mangrove poles on Figure 6 during low tides on the shoreline illustrates the remnants of suspended buildings which were far away from the sea. Due to coastal erosion, this settlement was almost completely wiped out and now found in the Atlantic Ocean. People were thus forced to retreat backwards into the land as the sea advances. This showed that most parts of the built-up areas where the people of Toube lived before 1984 have been submerged by the Atlantic Ocean. The submergence of Toube confirms earlier reports by [9] which predicted the submergence of the West African coastline, from the orange dunes in Mauritania to the dense tropical forests in Cameroon (where Toube is found) to be underwater by the end of the century as a direct consequence of climate change.

\subsection{Development Implications of Shoreline Change on the Fishing Communities of Toube}

The retreating nature of the shoreline of Toube has had severe impacts on the infrastructure of this locality as homes and fish processing units are destroyed annually in the course of the rainy season. As the sea keeps advancing, buildings and fish processing units are completely submerged in water. As a matter of fact, residential homes and fish processing units are being destroyed and relocated inland at very high costs every year (Figure 7). Coastal erosion affects both the houses and barns of the inhabitants which negatively affects their livelihood. Figure 7 shows the remnants of destroyed houses and barns in Toube. The construction of the infrastructure entails huge cost due to the regular coastal erosion and subsidence of the land, the people are forced to rebuild each time their infrastructure gets destroyed. This justifies the view that sea-level rise, coastal erosion, saltwater intrusion, and flooding will have significant impacts on coastal communities and economies [14]. 
Money which ought to have been used in improving the livelihoods is repeatedly used in rebuilding destroyed houses.
The monetary losses of the destroyed infrastructure incurred by the inhabitants of Toube are presented in Tables 3 and 4.

Table 3. Cost of destroyed fishing processing units along the Toube Coastline.

\begin{tabular}{|c|c|c|c|c|c|}
\hline \multirow[b]{2}{*}{ Area } & \multicolumn{2}{|c|}{ Number of barns destroyed } & \multicolumn{2}{|l|}{ Cost of relocating destroyed barns } & \multirow[b]{2}{*}{$\begin{array}{l}\text { Total Cost in } \\
\text { (FCFA) }\end{array}$} \\
\hline & $\begin{array}{l}\text { No of crayfish } \\
\text { barns destroyed }\end{array}$ & $\begin{array}{l}\text { No of fish barns } \\
\text { destroyed }\end{array}$ & $\begin{array}{l}\text { Total cost of relocating destroyed } \\
\text { crayfish (njanga) barns (FCFA) }\end{array}$ & $\begin{array}{l}\text { Total cost of relocating } \\
\text { destroyed fish barns (FCFA) }\end{array}$ & \\
\hline Itiekot & 09 & - & 4500000 & - & 4500000 \\
\hline Big Toube & 16 & - & 13600000 & - & 13600000 \\
\hline Chekiri & 14 & 06 & 6300000 & 3600000 & 9900000 \\
\hline Small Toube & - & 98 & - & 63200000 & 63200000 \\
\hline Cap & 123 & 74 & 61200000 & 42500000 & 103700000 \\
\hline
\end{tabular}

Source: Toube Annual Council Report (2000-2017).

Table 3 showed that, the inhabitants of Toube have incurred huge monetary costs due to coastal erosion and subsidence as their fish and crayfish processing units are always destroyed. Field findings revealed that a total cost of 85.600.000FCFA was incurred for the relocation of 162 destroyed crayfish barns while 109.300.000FCFA was incurred for the relocation of 217 fish barns that were destroyed. The results further showed that the losses incurred in terms of monetary cost varied across the study area with Cap having the highest losses (103.700.000FCFA) and Itiekot being the least (450000FCFA). Besides, while some neighbourhoods incurred losses both in terms of the destruction and relocation of crayfish and fish barns (Chekiri and Cap), other neighbourhoods (Itiekot, Big Toube and Small Toube) do not incur the same losses because they constitute neighbourhoods where just crayfish fishing (Itiekot, Big and Toube) is carried and areas where only fish exploitation (Small Toube) is carried out. Apart from the losses incurred due to the destruction and relocation of fish and crayfish barns, the inhabitants of the fishing community of Toube also bear huge losses as their homes are destroyed by coastal erosion and subsidence. This corroborates the findings of [15], who noted that coastal erosion has devastating effects on the environment and human infrastructures such as the destruction of infrastructures like roads, houses, salinization of water and soils, degradation of ecosystems and flooding. The findings of [16] also had much commonality with the above findings as he averred that coastal erosion is a serious threat to man and the environment in Ghana. [16] further noted that in some areas of Western Ghana, 17 coastal inhabitants lost their buildings to coastal erosion over a 26 -year period. This is also in conformity with the findings of [17] suggesting that noted the beach in Oman is shrinking as valuable property on the beach is being lost and structures are collapsing into the sea as a result of coastal erosion in Oman.

Table 4 shows the estimated cost of destroyed settlement in Ntoube between 1984 and 2017. Table 4 revealed that, a total of 264 "carry houses" (houses that can be transported from their original location without scattering) have been relocated at a total cost of 21.105.000FCFA between 1984 and 2017.

Table 4. Estimated cost of destroyed settlements in Toube from 1984 to 2017.

\begin{tabular}{lllll}
\hline Neighbourhood & $\begin{array}{l}\text { No of 'Carry houses' } \\
\text { destroyed }\end{array}$ & $\begin{array}{l}\text { Estimated cost of relocating } \\
\text { 'carry houses' (FCFA) }\end{array}$ & $\begin{array}{l}\text { No of 'spinning houses' } \\
\text { destroyed }\end{array}$ \\
\hline Itikot & 18 & 1359000 & $\begin{array}{l}\text { Estimated cost of relocating } \\
\text { 'pinning houses'(FCFA) }\end{array}$ \\
Big Toube & 43 & 3246500 & 33 \\
Chekiri & 14 & 938000 & 61 & 221400 \\
Small Toube & 53 & 4001500 & 26 & 115 \\
Cap & 136 & 1156000 & 176 & 60390000 \\
Total & 264 & 21105000 & 411 & 129040000 \\
\hline
\end{tabular}

Source: Field Work (2017).

Cap accounts for the greatest number of relocated "carry houses" (136), followed by Small Toube (53), Big Toube (43), Itiekot (18) and Chekiri (14). Only the relocation cost is considered to represent the losses incurred because, once a "carry house" is constructed and has to be carried further afield, costs are only incurred in the course of transportation. As such, the inhabitants keep shifting their houses inland (retreating) and as they do, they tend to bear a continuous relocation cost on a yearly basis. Furthermore, much financial costs have been incurred in the relocation of "pinning houses" (houses which cannot be relocated if they are not scattered and dismantled). The results revealed that a total of
251084000FCFA was incurred to destroy and relocate houses further inland. In absolute terms, Cap (176) has the highest number of destroyed houses followed by Small Toube (115), Big Toube (61), Itiekot (33) and Chekiri (26) from a total of 411 "pinning houses" destroyed in the entire area within 1984 to 2017. Summing the estimated cost involved in relocating "carry and pinning houses", it is ostensibly clear that severe infrastructural loss amounting to 467.089.000FCFA between 1984 and 2017 have been incurred due to the erosion and subsidence of their land. This has a negative effect on the livelihoods of the inhabitants of Toube as these barns and houses are part of their livelihood assets. 


\section{Conclusion}

The main aim of this study was to examine the effects of shoreline change on the fishing community of Toube. Fishing is a lucrative economic activity that has sustained the livelihoods of those directly and indirectly involved in it through its numerous benefits (source of employment, income, protein) amongst others. Despite the benefits derived from fishing, however, the entire island of Toube is under serious threat from coastal erosion and submergence of the land due to sea level rise which has severely affected the inhabitants of the fishing community of Toube despite the existence of adaptation strategies. This shows that, shoreline change has negatively affected the livelihoods of the inhabitants of this fishing community and needs to be addressed. The findings suggest long and short-term measures to curtail the situation. For short term measures, three strategies are proposed. Firstly, the diversification of livelihood activities of inhabitants involved in fishing by taking other non-fishing jobs (farming, petty trading, transportation and hunting) to generate income that may sustain them during unfavourable fishing seasons. Secondly, the use of sand bags along the shoreline to reduce the intensity of the incoming waves from eroding the land and thirdly, the construction of more 'carriable houses' than 'noncarriable' houses because carriable houses are cheaper to construct and less costly to relocate than the carriable houses. Long term measures include the creation of a buffer zone between the shoreline and the built-up area (at least $25 \mathrm{~m}$ ) away from the shoreline with mangrove trees planted to as natural barriers against coastal erosion.

\section{References}

[1] Bardach, J. E, (1989). "Global Warming and the Coastal Zone". Climatic Change 15: 117-150.

[2] Warrick, R. A, Barrow, E. M and Wigley, T. M. L (1993) (eds.). Climate and Sea Level Change: Observations, Projections and Implications. Cambridge: Cambridge University Press.

[3] Bagli, S., and Soille, P. (2003). Morhological Automatic Extraction of Pan-European coastline from Landsat ETM +images. International Symposium on GIS and Computer Cartography for Coastal Zone Management, October 2003, Genova.

[4] Mills, J. P., Buckley, S. J., Mitchell, H. L., Clarke, P. J., and Edwards, S. J. (2005). "A Geomatics data Integration Technique for Coastal Change Monitoring". Earth Surface Processes and Landforms, 30, 651-664.

[5] Bismita, B. (2014). Effects of coastal Erosion on the fishing community livelihoods: A focus on the East Midnapore coast, West Bengal. Tata Institute of Social Sciences Mumbai. India.
[6] IPCC (2001a). Climate Change 2001: Impacts, Adaptation, and Vulnerability. Prepared under the guidance of Working Group II Cochairmen Osvaldo Canziani (Argentina) and James McCarthy (US). Cambridge University Press, Cambridge, United Kingdom and New York, NY, USA.

[7] IPCC (2001b). Climate Change (2001): Third Assessment Report (TAR). World Meteorological Organization and United Nations Environment Programme, Geneva, Switzerland.

[8] IPCC (2007) Climate Change 2007. In Intergovernmental Panel on Climate Change (IPCC). World Meteorological Organization and United Nations Environment Programme, Geneva, Switzerland.

[9] IRIN-Integrated Regional Information Networks (2008): WEST AFRICA: Coastline to be submerged by 2099. Part of the UN office for the Coordination of Humanitarian Affairs (http://www.irinnews.org/Report.aspx?ReportId=79986, December 21st 2008).

[10] Brooks, N., Hall, J. and R. J. Nicholls (2006): Sea-Level Rise: Coastal Impacts and Responses. German Advisory Council on Climate Change. WBGU, Norwich-Berlin (http://www.wbgu.de/wbgu_sn2006_ex03.pdf, September 27th 2008).

[11] Béné, C. (2003). "Fisheries Development and their Impacts on the Livelihoods of Fishing Communities in West Africa: An overview". Journal of Food Agriculture and Environment. Vol. 1 (1): 128-134.

[12] Munji, A., Youssoufa, B., Nkwatoh, A. I., Monica, S. and Olufunso, S. (2013). "Vulnerability to Coastal Flooding and Response Strategies: The case of settlements in Cameroon Mangrove Forests". Environmental Development, 5. 54-72.

[13] Brouillette-Jacobson, D. M. (2008). Analysis of Coastal Erosion on Martha's Vineyard, Massachusetts: A Paraglacial Island. Masters Theses, University of Massachusetts Amherst, 446p.

[14] Molua, E. (2010). Climate and Location Vulnerability in Southwestern Cameroon: assessing the options and cost of protection to property in coastal areas. CEEPA Discussion Paper No 46, Centre for Environmental Economics and Policy in Africa, University of Pretoria.

[15] Alves, B., Angnuureng, D.B., Mrand, P. et al. (2020). A review of coastal erosion and flooding risk and best management practices in West Africa: What has been done and should be done. Journal of Coastal Conservation 24(38).

[16] Oteng-Ababio, M., Owusu, K. and Addo, K. P. (2011). "The vulnerable state of the Ghana coast: The case of FaanaBortianor". JAMBA Journal of Disaster Risk Studies, Vol. 3, No. 2, pp. 429-442.

[17] Salim, M. A. and Ali, S. (2009). Coastal Erosion and its Impact on Society on the Batinah Coast, Sultanate of Oman. Geographische Rundschau International Edition Vol. 5, No. $2 / 2009$. 